\title{
The study of dependency between land-use coverage and parcel boundaries
}

\author{
Piotr Benduch, ${ }^{1,}$ \\ ${ }^{1}$ AGH University of Science and Technology, Faculty of Mining Surveying and Environmental Engineering, Department of Geomatics, \\ al. Mickiewicza 30, 30-059 Kraków, Poland
}

\begin{abstract}
Land-use constitutes a part of the earth's surface which is used in a specific, unitary manner. In Poland, data concerning land-uses are registered in the Real Estate Cadastre. This data plays an important role, inter alia, in the context of land properties taxation as well as performing statistical analyses in the field of spatial structure and land development form on various levels of administrative division of a country. Data on land-uses also form basis for activities aimed to agricultural and forest land protection. In this article, the study concerning identification of dependency between parcel boundaries and land-use coverage has been conducted. Occurrence of such a dependency is determined by the characteristics of Polish legal regulations and the fact of carrying out the Real Estate Cadastre in the form of informational system. On this basis it could be concluded that parcel boundary is one of determinants influencing the coverage shape of specific land use form. Using GIS tools, the assessment of size of this impact has been performed at the level of individual land properties as well as the whole cadastral districts. The spatial structure of land-uses in selected cadastral districts in southern Poland has been also compared. The results of analysis were presented both in graphical and analytical form.
\end{abstract}

\section{Introduction}

According to the definition contained in Geodetic and Cartographic Law [1], the real estate cadastre is a collection of data on land, buildings and business premises, their owners as well as other entities that manage or possess the land, buildings and premises. The cadastral parcel is a leading object of the real estate cadastre. This follows from the Roman legal principle "superficies solo cedit" which means that anything placed upon the ground is attached to that ground [2]. In addition to the cadastral parcel, being a continuous area of land subject to the same rights, the cadastre also contains data on land uses, i.e. on land zones developed or utilized in a specific, uniform manner. These zoning data are widely used. In Polish conditions, they are especially significant for determining land tax assessment bases [3]. This means that any changes in the extent and type of land use also carry economic consequences [4]. Moreover, land use data are applicable to numerous statistical analyzes regarding the spatial structure of land use $[5,6]$. These data are also essential for the implementation of activities aimed at legal protection of specific areas, e.g. forests [7]. A general conclusion to be drawn is that the data on the land entered into the real estate cadastre constitute a multitasking model of the factual status of land use.

The boundaries of a given land property or its part are one of the factors determining the use of this land in a specific manner. Enforcement of property rights may lead to significant changes in this respect. The range of these changes usually coincides with the course of parcel boundaries. This may be confirmed by the implementation of land reparcelling and exchange proceedings, resulting in the transformation of the spatial structure of the land covered by this procedure [8-10]. A similar situation, although significantly smaller in its scope and scale, may occur for the real estate subdivision, and even in the case of delimitation proceedings aimed at determination of boundaries [11], which is often necessary before the construction investment commences. Therefore, the fact that real estate boundaries are taken into consideration in space-time modeling of the extent of land use zones should not be surprising [12-17]. Nevertheless, in practice, the method of land development often turns out to be divergent from the actual course of parcel boundaries, which is illustrated in Figure 2A. Other factors, including transport accessibility, intended purpose in the local land use plan, topography or ownership structure of farms in a given region, are also important.

It should also be taken into account that the actual manner of land development visible on the orthophotomap is represented in the database of the real estate cadastre through the appropriate classes of spatial objects. Depending on the legal regulations which are in force in a given country, as well as on the characteristics of the national profile of the cadastre, there may be more or less significant differences in detail, accuracy and updatedness of the data on land use. In any case, however, these data will only be a simplified model of the factual

* Corresponding author: pbenduch@agh.edu.pl 
status of land development, dedicated to specific needs and applications.
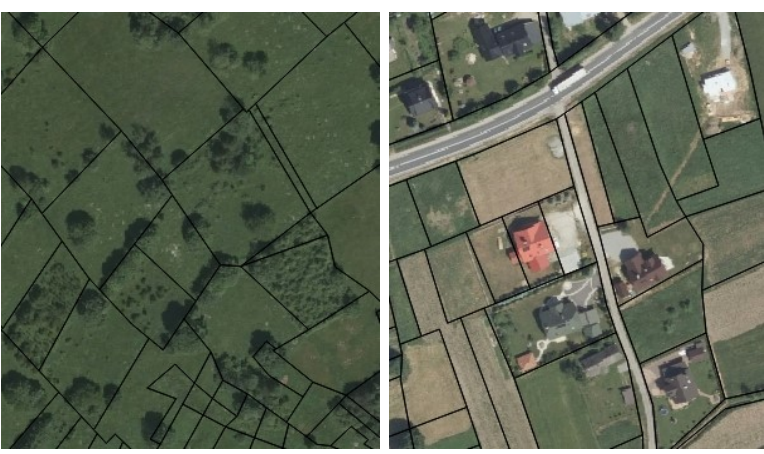

Fig. 1. Actual manner of land development and parcel

A) No correlation boundaries

A) No correlation $\quad$ B) Strong correlation

This research paper undertakes the studies whose main objective is to demonstrate a relationship between the extent of land use contours and boundaries of cadastral parcels in the Polish conditions. In addition, the structure of land use in selected cadastral districts is analyzed and compared. All the analyzes were carried out based on the data from the County Geodetic and Cartographic Documentation Center. The location of research area is presented in Figure 2.

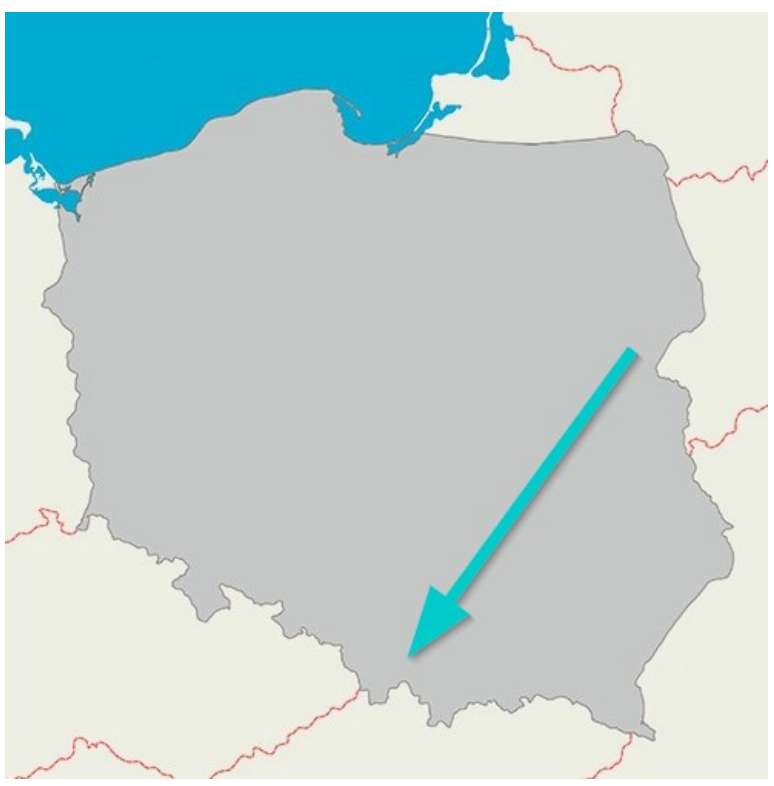

Fig. 2. Location of the research area

\section{Land use in Polish real estate cadastre}

Under the current legal status, according to the UML application scheme constituting Appendix No. 1a to the Regulation on the Register of Land and Buildings [18], the class representing land use in the database of the real estate cadastre is EGB_KonturUzytkuGruntowego.

In addition to the geometry and the identifier, the legislator also included the attribute OFU in the list of attributes, representing the type of land use. Therefore, the conceptual model of the cadastral data on land seems simple and transparent. Only the fact that the class EGB_KonturUzytkuGruntowego representing land use in accordance with the UML application scheme is directly related to a cadastral district and not to a parcel, can be considered a certain complexity. On the other hand, $\S 60$ of the Regulation [18] providing descriptive data for the parcel, also contains information describing surface areas of contours of land use zones and quality classes within the parcel. The EGB_Klasouzytek class, which represents the common part of the land use contour and the classification contour within the boundaries of a given land parcel, which is the effect of intersection of the geometry of the discussed objects, turns out to be helpful in this respect. At this point, it is worth mentioning that only agricultural and forest lands are subject to soil classification, and the course of classification contours in the cadastre are adopted based on the classification map prepared under separate regulations.

\begin{tabular}{|c|} 
EGB_OgolnyObiekt \\
«FeatureType» \\
EGB_KonturUzytkuGruntowego
\end{tabular}

Fig. 3. Class representing land use in Polish profile of real estate cadastre

However, the key problem is capturing reliable data on the extent (geometry) and type of land use (OFU). Currently, the types of land uses permissible by law are divided into six groups, which are presented in Table 1.

Basic principles for classifying land to individual land use zones have been included in Appendix 6 to the Regulation on the Register of Land and Buildings [18]. These principles are too general, though. They also contain numerous references to other legal acts. Lack of unambiguous rules makes determining the extent (geometry) and type of land use (OFU) problematic [19]. This also applies to entering land use changes during the construction process [20], implementation of road investments [21], or changes occurring due to natural activities, such as forest succession [22] or river meanders [23]. Due to highly dynamic changes in this respect, maintaining the data on land use zones in the cadastre constantly updated is sometimes difficult [24]. Despite the activities being carried out throughout the country and related to the modernization of the registers of land and buildings, there still are outdated data describing the status of land use in many areas. The subject literature discussing the process of capturing the data on the extent and types of land use zones points out to the potential of photogrammetric methods $[25,26]$, which is also confirmed by the fragments of the orthophotomap presented in Figure 2. 
Table 1. Groups and types of land uses

\begin{tabular}{|c|c|c|}
\hline No. & Group & Land use type \\
\hline 1 & $\begin{array}{c}\text { Agricultural } \\
\text { land }\end{array}$ & $\begin{array}{c}\text { Arable land; Orchards; Permanent } \\
\text { meadows; Permanent pastures; } \\
\text { Developed agricultural land; Land under } \\
\text { ponds; Land under ditches; Land covered } \\
\text { with trees and shrubs on agricultural land; } \\
\text { Wasteland }\end{array}$ \\
\hline 2 & Forest land & $\begin{array}{c}\text { Forests; Land covered with trees and } \\
\text { shrubs }\end{array}$ \\
\hline 3 & $\begin{array}{c}\text { Developed and } \\
\text { urbanized land }\end{array}$ & $\begin{array}{c}\text { Residential areas; Industrial areas; Other } \\
\text { developed areas; Undeveloped urban } \\
\text { areas or areas under development; } \\
\text { Recreational areas; Fossil land; Roads; } \\
\text { Railway areas; Other communication } \\
\text { areas; Land intended for construction of } \\
\text { public roads and railways }\end{array}$ \\
\hline 4 & $\begin{array}{c}\text { Land under } \\
\text { waters }\end{array}$ & $\begin{array}{c}\text { Land under internal sea water; Land } \\
\text { under surface flowing water; Land under } \\
\text { surface still water }\end{array}$ \\
\hline 5 & \multicolumn{3}{|c|}{ Other types of land } \\
\hline 6 & $\begin{array}{c}\text { Ecological areas, denoted by the symbol consisting of the } \\
\text { letter "E" and the symbol of the appropriate land use }\end{array}$ \\
\hline
\end{tabular}

In the context of the reliability of the data on land uses entered into the real estate cadastre, the fact that the legislator did not provide for the possibility of recording the source of data capture or the estimated accuracy used to determine the extent of land use contours should be considered adverse. This information could prove useful for the needs of conducting comprehensive spatial analyzes in terms of quality and completeness of land use data, as it is the case with the boundaries of real properties [27]. Taking into account technical standards for topographic surveys [28], it can be concluded that the data on the location of land use turn points should be captured using detailed surveys which ensure the accuracy of not less than $0.50 \mathrm{~m}$ relative to the nearest points of the horizontal geodetic control network and the measuring network. These requirements, of course, are significantly less restrictive than in the case of a numerical description of the boundaries of a cadastral parcel [29]. However, if the land use contour coincides with the parcel boundary, then it can be assumed that the mean error with which the location of the boundary point has been established, will also be identical for the turn point of the land use contour. Both Figure 2B and the fragment of the archival cadastral map in the analogue form presented in Figure 4 are proofs of such an assumption.

It is easy to notice that the contours of land use zones and quality classes marked with a dotted line coincide with the boundaries of the cadastral parcels. This is, to some extent, a consequence of the law which was in force when land registers were established back in the 1970s [30], under which the contours of land use zones with surface areas of less than 1 are were not individually entered, but included in the predominant area of the surrounding or adjacent land use. As a result, the data on land uses was subjected to a kind of generalization, which, however, should be considered reasonable and fully justified. Similar provision is contained in Appendix 6 to the current Regulation [18]. There is a difference, however, consisting in that the contour of the land use with a surface area smaller than 1 are should be included into the adjacent land use which is the most similar in terms of its characteristics, and which occurs within the boundaries of the real property. This is yet another proof that there is a strong dependence between the parcel boundary and the extent of land use of a specific type.

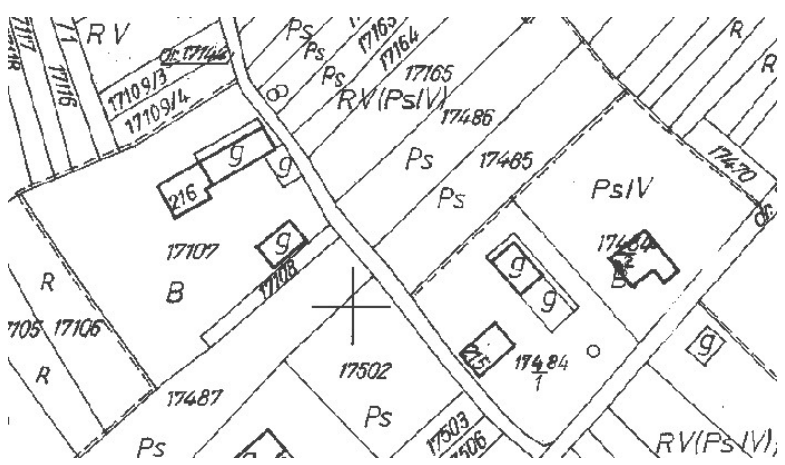

Fig. 4. Fragment of cadastral map in analogue form

It should also be noted that analogue cadastral maps, as the one illustrated in Figure 4, were used during the conversion of the land register survey from a traditional form to a digital form. The visible trend of closing contours of land uses within the boundaries of parcels has been largely preserved, which also proved to be practical in terms of attention to topological consistency of the database.

\section{Research methodology}

The course of the research studies aimed at determining the level of dependence between the boundaries of cadastral parcels and land use contours has been illustrated by means of the block diagram in Figure 5 .
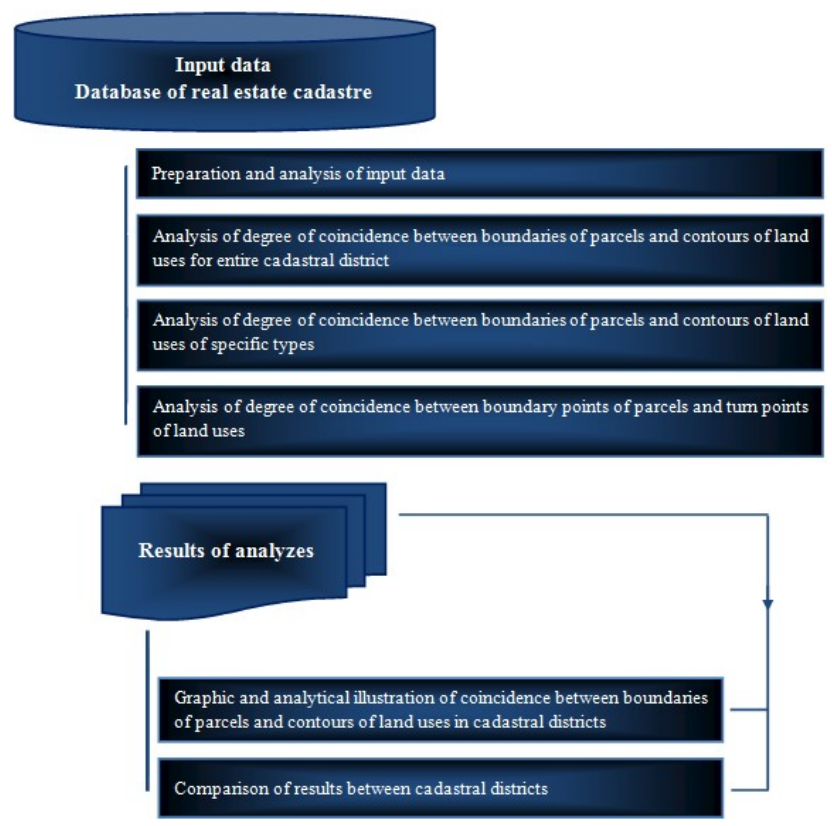

Fig. 5. Block diagram of the course of subject analyzes 
In addition, it should be emphasized that the analyzes concerned exclusively the relationship between the parcel boundary and the extent of the land use contour, constituting the representation of the real world in the database of the real estate cadastre. The compliance of the data with the factual status was not verified.

\section{Characteristics of study area}

The analyzes were carried out on two selected cadastral districts located in southern Poland in the Małopolska province, county of Sucha Beskidzka:

- district of Zawoja - surface area of the district: 10,088

[ha]; number of cadastral parcels: 34,051; rural areas with average density of development; upland and mountainous topography,

- district of Maków Podhalański - surface area of the district: 2,012 [ha]; number of cadastral parcels: 10,135; urban-rural areas with average density of development; upland and mountainous topography.

Both research areas have been subject to the modernization of the register of land and buildings in recent years. Therefore, good updatedness of the cadastral data could be expected, as well as their consistency with the factual status. The structure of land use in the analyzed cadastral districts is illustrated in Figure 6 and Figure 7.

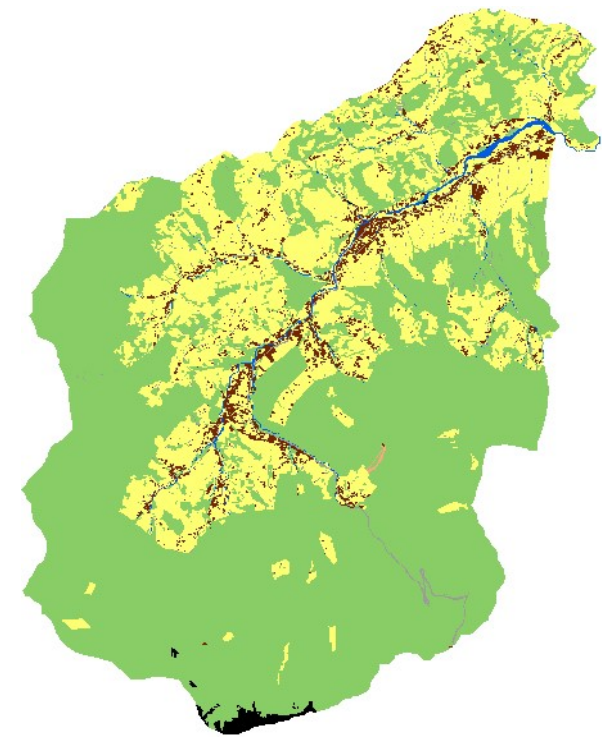

\begin{tabular}{ccc} 
Legend & Manner of use & Share \\
\hline Developed and urbanized land & $3.27 \%$ \\
Roads and communication areas & $1.36 \%$ \\
Land under waters & $0.73 \%$ \\
Forests and wooded land & $64.64 \%$ \\
Agricultural land & $29.48 \%$ \\
Other land & $0.04 \%$ \\
Wasteland & $0.49 \%$
\end{tabular}

Fig. 6. Structure of land use for Zawoja cadastral district

In the areas of Zawoja and Maków Podhalański cadastral districts, forests and wooded land prevail. If compared to Zawoja, Maków Podhalański has a larger share of agricultural land as well as developed and urbanized land. In both analyzed areas, development clusters occur in the vicinity of the main roads. In addition, in the urban part of Maków Podhalański, there is a marked increase in the share of built-up areas. Both in Zawoja and in Maków Podhalański cadastral districts, the share of other areas and wasteland is small, not exceeding $1 \%$. It is also worth noting that the increased percentage of land under waters in Maków Podhalański is associated with the presence of the Skawa river bed in the southern part of the district, which can be seen clearly in Figure 7 . In both analyzed study areas, agricultural and forest lands are most often adjacent to each other, followed by agricultural land and roads.

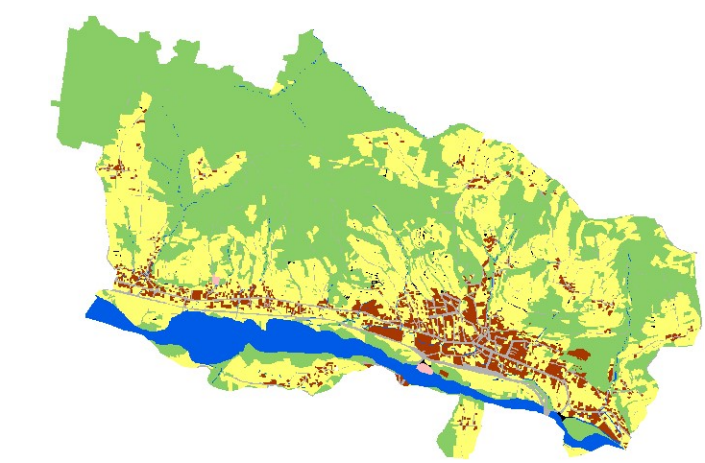

\begin{tabular}{ccc} 
Legend & Manner of use & Share \\
\hline & Developed and urbanized land & $6.88 \%$ \\
Roads and communication areas & $3.30 \%$ \\
Land under waters & $6.58 \%$ \\
Forests and wooded land & $47.40 \%$ \\
Agricultural land & $35.54 \%$ \\
Other land & $0.11 \%$ \\
Wasteland & $0.20 \%$
\end{tabular}

Fig. 7. Structure of land use for Maków Podhalański cadastral district

\section{Research results}

The first analysis consisted in the determination of the degree of coincidence between the contours of land uses and the boundaries of cadastral parcels. The results are illustrated in Figure 8 and Figure 9.

Based on the graphical presentation of the results of the conducted analyzes, a high degree of coincidence between the contours of land uses and the boundaries of cadastral parcels was found, which was comparable in both areas. This conclusion was also confirmed by further calculations, the results of which are presented in Table 2.

In Zawoja cadastral district, $70.0 \%$ of the contours of the land uses coincide with the boundaries of the parcels. The total length of the shared sections of the boundaries of the parcels and the contours of the land uses exceeds 1,200 kilometres. In Maków Podhalański, this percentage is higher and amounts to $76.2 \%$, which translates into the length of over 510 kilometres. Obviously, the percentage of the parcel boundaries that coincide with the contours of the land uses in both study areas is respectively smaller. In practice, already at this stage of the analysis, it can be 
stated that there is a strong dependence between the extent of land use zones and the course of real estate boundaries.

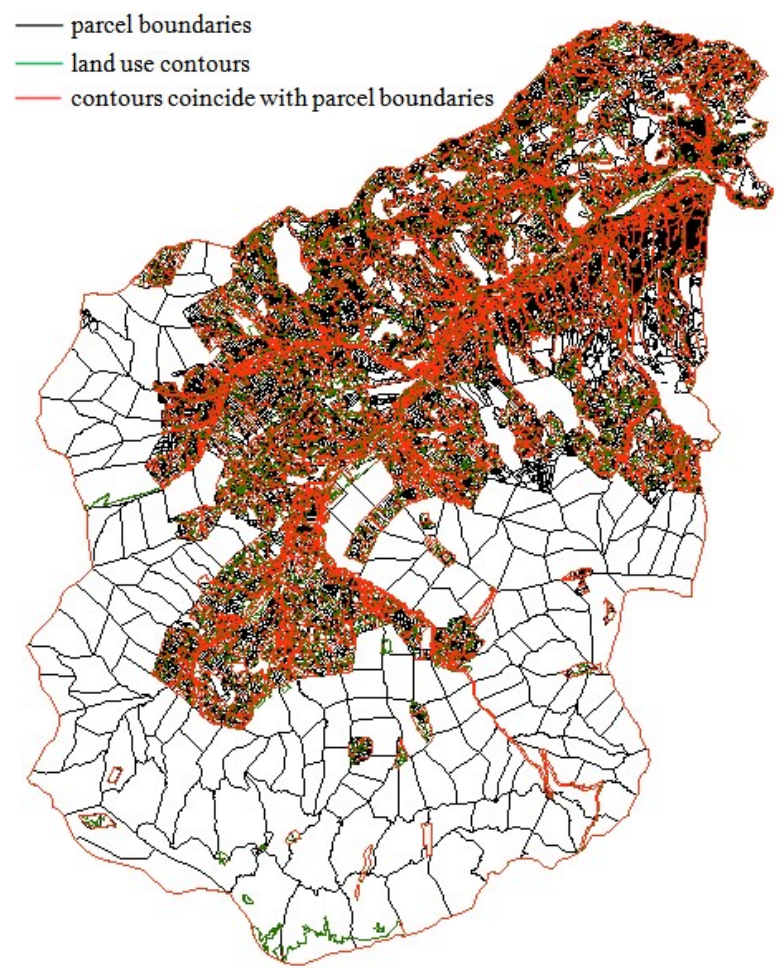

Fig. 8. Analysis of degree of coincidence between boundaries of parcels and contours of land uses - Zawoja cadastral district

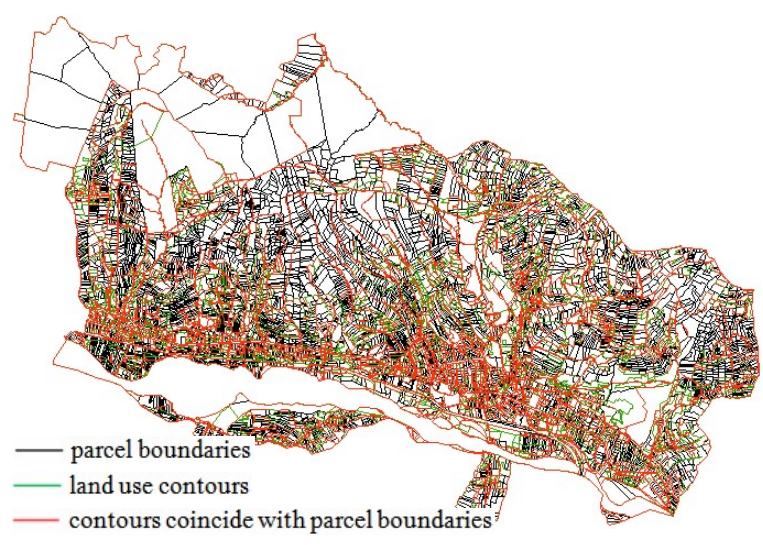

Fig. 9. Analysis of degree of coincidence between boundaries of parcels and contours of land uses - Maków Podhalański cadastral district

The next stage of the research involved the analysis of the coincidence of the contours of land uses of specific types with the boundaries of cadastral parcels. In order to ensure the transparency of the analyzes, not all the types of land uses provided for in the Regulation [18] and listed in Table 1 were included. The division was made according to the legend presented in Figures 5 and 6 . The results are demonstrated in Table 3 and Table 4.
Table 2. Analytical presentation of results of analyzes of coincidence between parcel boundaries and contours of land use

\begin{tabular}{|c|c|c|}
\hline \multirow{2}{*}{ Description } & \multicolumn{2}{|c|}{ Cadastral district } \\
\cline { 2 - 3 } & Zawoja & $\begin{array}{c}\text { Maków } \\
\text { Podhalański }\end{array}$ \\
\hline $\begin{array}{c}\text { Percentage of land use } \\
\text { contours coinciding with } \\
\text { boundaries of parcels }\end{array}$ & $70.0 \%$ & $76.2 \%$ \\
\hline $\begin{array}{c}\text { Percentage of boundaries } \\
\text { of parcels coinciding with } \\
\text { land use contours }\end{array}$ & $38.2 \%$ & $49.9 \%$ \\
\hline
\end{tabular}

Table 3. Analytical presentation of results of analysis of coincidence between contours of land uses of specific types and boundaries of parcels - Zawoja cadastral district

\begin{tabular}{|c|c|c|c|}
\hline Land use & $\begin{array}{c}\text { Total length of } \\
\text { land use } \\
\text { contours [km] }\end{array}$ & $\begin{array}{c}\text { Total length of } \\
\text { contours } \\
\text { coinciding with } \\
\text { boundaries of } \\
\text { parcels [km] }\end{array}$ & $\begin{array}{c}\text { Percentage } \\
\text { share }\end{array}$ \\
\hline $\begin{array}{c}\text { Developed and } \\
\text { urbanized land }\end{array}$ & 362.395 & 249.318 & $69 \%$ \\
\hline $\begin{array}{c}\text { Roads and } \\
\text { communication } \\
\text { areas }\end{array}$ & 447.070 & 387.612 & $87 \%$ \\
\hline $\begin{array}{c}\text { Land under } \\
\text { waters }\end{array}$ & 116.195 & 101.886 & $88 \%$ \\
\hline $\begin{array}{c}\text { Forests and } \\
\text { wooded land }\end{array}$ & 595.210 & 446.602 & $75 \%$ \\
\hline $\begin{array}{c}\text { Agricultural } \\
\text { land }\end{array}$ & 1399.143 & 922.309 & $66 \%$ \\
\hline Other land & 2.735 & 2.618 & $96 \%$ \\
\hline Wasteland & 13.218 & 3.614 & $27 \%$ \\
\hline
\end{tabular}

Table 4. Analytical presentation of results of analysis of coincidence between contours of land uses of specific types and boundaries of parcels - Maków Podhalański cadastral district

\begin{tabular}{|c|c|c|c|}
\hline Land use & $\begin{array}{c}\text { Total length of } \\
\text { land use } \\
\text { contours [km] }\end{array}$ & $\begin{array}{c}\text { Total length of } \\
\text { contours } \\
\text { coinciding with } \\
\text { boundaries of } \\
\text { parcels [km] }\end{array}$ & $\begin{array}{c}\text { Percentage } \\
\text { share }\end{array}$ \\
\hline $\begin{array}{c}\text { Developed and } \\
\text { urbanized land }\end{array}$ & 140.840 & 107.857 & $77 \%$ \\
\hline $\begin{array}{c}\text { Roads and } \\
\text { communication } \\
\text { areas }\end{array}$ & 266.682 & 260.762 & $98 \%$ \\
\hline $\begin{array}{c}\text { Land under } \\
\text { waters }\end{array}$ & 70.854 & 69.344 & $98 \%$ \\
\hline $\begin{array}{c}\text { Forests and } \\
\text { wooded land }\end{array}$ & 303.710 & 225.234 & $74 \%$ \\
\hline $\begin{array}{c}\text { Agricultural } \\
\text { land }\end{array}$ & 410.138 & 264.472 & $64 \%$ \\
\hline Other land & 0.892 & 0.892 & $100 \%$ \\
\hline Wasteland & 16.747 & 7.392 & $44 \%$ \\
\hline
\end{tabular}

It turns out that the highest degree of coincidence between the land use contours and the boundaries of parcels in both study areas occurs for "other areas". In 
Maków Podhalański, 100\% coincidence for the land uses of this type with the boundaries of parcels was noted. However, it should be taken into account that "other areas" in both cadastral districts are very scarce. A high percentage of coincidence between the boundaries of the parcels and the contours of land uses was also noted in the case of roads and communication areas as well as land under waters. The situation is similar in both study areas and is a consequence of the laws which are in force in Poland regarding the entering of the parcels occupied by roads and flowing waters into the cadastre. The lowest level of coincidence was observed for wasteland which, as it is the case with "other areas", occurred sporadically in the research area. In the case of agricultural land, which includes arable land, pastures, meadows, as well as land occupied by ditches and woodlots, a lower than the average coincidence between the land use contours and the boundaries of the parcels was noted both in Zawoja and in Maków Podhalański.

Finally, the location of turn points of the contours of land uses was examined against the location of the boundary points of parcels. The results are demonstrated in Table 5 .

Table 5. Number and percentage of turn points of contours of land uses coinciding with boundary points of parcels

\begin{tabular}{|c|c|c|c|}
\hline $\begin{array}{c}\text { Cadastral } \\
\text { district }\end{array}$ & $\begin{array}{c}\text { Number of } \\
\text { boundary } \\
\text { points }\end{array}$ & $\begin{array}{c}\text { Number of } \\
\text { turn points } \\
\text { of contours } \\
\text { of land uses }\end{array}$ & $\begin{array}{c}\text { Number of } \\
\text { shared } \\
\text { points }\end{array}$ \\
\hline Zawoja & 111040 & 92234 & 61548 \\
\hline $\begin{array}{c}\text { Maków } \\
\text { Podhalański }\end{array}$ & 49359 & 42170 & 35153 \\
\hline
\end{tabular}

It was found that in the cadastral districts of Zawoja and Maków Podhalański, respectively $66.7 \%$ and $83.4 \%$ of the turn points of the contours of the land use zones coincided with the boundary points of the parcels. Such a result was expected due to the previously discussed specificity of the Polish legal regulations regarding the entering of land uses into the real estate cadastre. It is also important to maintain the cadastre in the form of an information system and to strive to keep the proper topological relationships between the various objects representing the extent of rights assigned to the land as well as the manner of land development.

Based on the results presented in Table 5, it can be stated that the turn points of the contours of the land use zones that coincide with the boundary points, also inherit the individual attributes of these points, including the accuracy declared in the form of the attribute: mean error of the boundary point location relative to the first-order geodetic control. Such information could prove useful, also in the implementation of research studies in the field of accuracy of surface areas of the contours of individual land use zones. Currently, such analyses for the model of the factual status of land development, contained in the Polish real estate cadastre, cannot be performed, which adversely affects the reliability of the land use data and increases the uncertainty of all procedures requiring the knowledge of this spatial information.

\section{Conclusions}

The undertaken research studies allowed to formulate the following conclusions:

- The data on land uses entered into the real estate cadastre can be treated as a multitasking model of the factual status of land use. This model is subject to appropriate simplifications provided for in the secondary legislation.

- In addition to the historic events and conditions, Polish legal regulations on the maintenance of the real estate cadastre in a specific, uniform manner, are the main reason for the occurrence of strong dependence between the extent of the land use and the boundary of the cadastral parcel. Due to the fact that a similar situation often takes place in the real world, the occurrence of this relationship should be finally considered positive. The boundary of the parcel is one of the determinants defining the manner of development and use of a part of the Earth's surface parcelled out from the surrounding area.

- Within the study areas, the vast majority of the contours of the land uses coincide with the boundaries of the cadastral parcels. An analogous conclusion can be drawn for the turn points of the contours and the boundary points of the parcels, which additionally confirms the research thesis formulated at the beginning.

- In consideration of the above, it seems possible to use the attributes of boundary points, especially regarding the accuracy of their location, in the context of the analyzes related to the extent and surface area of land use zones. In other words, in the case of coincidence between the boundary of the parcel and the contour of the land use, this contour inherits the attributes of a given boundary, which allows for further inference. Such a possibility does not exist, however, when the contour of the land use does not coincide with the boundary of the parcel.

- Currently, the applicable law does not provide for the need to enter the information such as a source of the land use data or estimated accuracy of the location of turn points of their contours. Therefore, it is not possible to carry out comprehensive and uniform analyzes confirming the reliability of the data contained in the cadastre and describing the factual status of land use which, in the light of the wide use of these data, should be considered adverse.

\section{Acknowledgment}

Publication supported by the Polish Ministry of Science and Higher Education as a part of the program of activities disseminating science from the project „Organization of the First International Science Conference - Ecological and Environmental Engineering”, 26-29 June 2018, Kraków. 


\section{References}

1. The Act of 17 May 1989 Geodetic and Cartographic Law (Official Journal 2017, No. 0, item 2101 consolidated text, as amended).

2. Hanus, P., Hycner, R., Kwartnik-Pruc, A. Magazyn Geoinformacyjny Geodeta, 10, pp. 26-31. (2013).

3. Benduch, P. Problematic aspects of determining the surface area of grounds, buildings and premises for cadastre and real estate taxation purposes. In the 10th International Conference "Environmental Engineering": selected papers. Vilnius Gediminas Technical University, Lithuania, April 27-28, 2017. (2017).

4. Benduch, P., Pęska, A. Infrastruktura i Ekologia Terenów Wiejskich, III/1/2016, pp. 787-800. (2016).

5. Warczewska, B., Warczewski, W. Infrastruktura i Ekologia Terenów Wiejskich, I/2/2017, pp. 319-332. (2017).

6. Wójcik-Leń J., Stręk Ż. The share of land belonging to non-resident owners in a village intersected by a motorway - case study. Geographic Information Systems Conference and Exhibition, GIS ODYSSEY 2017: Conference proceedings. 4th to 8th of September 2017, Trento - Vattaro, Italy, 2017, pp. 427-435. (2017).

7. Bielecka, E., Całka, B. Infrastruktura i Ekologia Terenów Wiejskich, 2/III/2012, pp. 163-173. (2012).

8. Leń, P., Król, Z. Journal of Ecological Engineering, Volume 17, Issue 5, pp. 232-239. (2016).

9. Stręk Ż. Engineering for rural development analysis of demand for land consolidation in Milejów commune, Łęczna district. Engineering For Rural Development, Jelgava, 24-26.05.2017, pp. 593-599. (2017).

10. Wójcik-Leń J., Sobolewska-Mikulska K.. Journal of Water and Land Development, No. 34, pp. 249-258. (2017).

11. Pęska, A. Geomatics and Environmental Engineering, 8, pp. 71-84. (2014).

12. Brown, D. G., Pijanowski, B. C., \& Duh, J. D. Journal of Environmental Management, 59(4), pp. 247-263. (2000).

13. Verburg, P. H., Schot, P. P., Dijst, M. J., Veldkamp, A. GeoJournal, 61(4), pp. 309-324. (2004).

14. Inan, H. I. Land Use Policy, 49, pp. 626-633. (2015).

15. Maleki, J., Hakimpour, F., Masoumi, Z. ISPRS International Journal of Geo-Information, 6(9), 273, pp. 1-22. (2017).

16. Sohl, T., Dornbierer, J., Wika, S., Sayler, K., Quenzer, R. Journal of Land Use Science, 12(4), pp. 197-217. (2017).

17. Mukhopadhyay, A., Hornby, D. D., Hutton, C. W., Lázár, A. N., Johnson, F. A., Ghosh, T. Land Cover and Land Use Analysis in Coastal Bangladesh. In Ecosystem Services for Well-Being in Deltas (pp. 367-381). Palgrave Macmillan, Cham. (2018).
18. Regulation of the Minister of Regional Development and Construction of 29 March 2001 on the register of land and buildings (Official Journal 2016, No. 0, item 1034 - consolidated text, as amended).

19. Benduch, P. Infrastruktura i Ekologia Terenów Wiejskich, III/1/2017, pp. 999-1015. (2017).

20. Gałuszka, Z., Hanus, P. Acta Scientifica Academiae Ostroviensis, 35, pp. 12-19. (2011).

21. Modelska, K. Infrastruktura i Ekologia Terenów Wiejskich, 2/III/2013, pp. 59-70. (2013).

22. Śmigielski, M., Pijanowski, J. M., Gniadek, J. Acta Sci. Pol. Formatio Circumiectus, 16(4), pp. 51-63. (2017).

23. Hanus, P., Pęska, A. Technical Aspects of Determining and Revealing Shore Lines in Real Estate Cadaster. In Geographic Information Systems Conference and Exhibition "GIS ODYSSEY 2016", 5th to 9th of September 2016, Perugia, Italy. (2016).

24. Konieczna, J. Infrastruktura i Ekologia Terenów Wiejskich, 1/II/2012, pp. 197-206. (2012).

25. Güler, M., Yomralığlu, T., Reis, S. Environmental Monitoring and Assessment, 127(1), pp. 155-167. (2007).

26. Kurczyński, Z., Bakuła, K. Przegląd Geodezyjny, 88(7), pp. 2-10. (2016).

27. Hanus, P., Pęska-Siwik, A., Szewczyk, R. Spatial analysis of the accuracy of the cadastral parcel boundaries. Computers and Electronics in Agriculture, 144, pp. 9-15. (2018).

28. Regulation of the Minister of Internal Affairs and Administration of 9 November 2011 on the technical standards for the performance of horizontal and height measurements and processing as well as transferring results of these measurements to the National Geodetic and Cartographic Resource (Official Journal 2011, No. 263, item 1572).

29. Hanus, P., Jasińska, E., Preweda, E. Analysis of the accuracy of determining the coordinates property borders. In the 9th International Conference "Environmental Engineering”, 22-23 May 2014, Vilnius, Lithuania. (2014).

30. Ordinance of the Ministers of Agriculture and Municipal Economy of 20 February 1969 on land registry (Official Journal 1969, No. 11, item 98). 